\title{
Simultaneous Recovery of Struvite and Irrigation Water for Agricultural Purposes Obtained from Dewatering Liquor through Electrodialysis
}

\author{
Petra Malíková *(D), Katrin Calábková (D), Silvie Heviánková, Jan Halfar (D), Iva Kotalová and Barbora Valová
}

check for

updates

Citation: Malíková, P.; Calábková, K.; Heviánková, S.; Halfar, J.; Kotalová, I.; Valová, B. Simultaneous Recovery of Struvite and Irrigation Water for Agricultural Purposes Obtained from Dewatering Liquor through Electrodialysis. Water 2021, 13, 3280. https://doi.org/10.3390/w13223280

Academic Editors: Christos S. Akratos and Laura Bulgariu

Received: 16 September 2021 Accepted: 17 November 2021 Published: 19 November 2021

Publisher's Note: MDPI stays neutral with regard to jurisdictional claims in published maps and institutional affiliations.

Copyright: (c) 2021 by the authors. Licensee MDPI, Basel, Switzerland. This article is an open access article distributed under the terms and conditions of the Creative Commons Attribution (CC BY) license (https:// creativecommons.org/licenses/by/ $4.0 /)$.
Department of Environmental Engineering, Faculty of Mining and Geology, VSB-Technical University of Ostrava, 17. listopadu 2172/15, 70800 Ostrava, Czech Republic; katrin.calabkova@vsb.cz (K.C.); silvie.heviankova@vsb.cz (S.H.); jan.halfar@vsb.cz (J.H.); iva.kotalova@vsb.cz (I.K.); barbora.valova@vsb.cz (B.V.)

* Correspondence: petra.malikova@vsb.cz

\begin{abstract}
Wastewater contains resources, which can be recovered for secondary use if treated properly. Besides research in zero liquid discharge solutions, the aim of the study was a simultaneous recovery of products from a wastewater treatment plant's dewatering liquor. To be specific, we investigated a simultaneous recovery of struvite and irrigation water using electrodialysis (ED) in laboratory experiments. Two products were obtained from ED—concentrate and diluate. The concentrate was precipitated to obtain struvite. On average, $11 \mathrm{~g}$ of wet precipitate (including $17.58 \%$ of dry solids) were obtained from $1 \mathrm{~L}$ of concentrate. Crystal phases were confirmed by powder X-ray diffraction (XRD), with showing $94-97 \%$ recovery of struvite, while the remaining 3-6\% were identified as hazenite. The average yield of crystal struvite was $1.76 \mathrm{~g}$. Both struvite and hazenite may further be used as a fertilizer. Next, we suggest using the second ED product, the diluate, as irrigation water if it meets the irrigation water requirements. Attention was paid to the concentrations of dissolved solids (DS) in diluate, which decreased by an average of $93 \%$ compared to the input values in the dewatering liquor. In line with the observed Czech or EU standards indicators, we can say that the diluate can be used in agriculture, namely as irrigation water (Category I-water suitable for irrigation).
\end{abstract}

Keywords: dewatering liquor; wastewater treatment plant (WWTP); struvite; irrigation water; electrodialysis; zero liquid discharge (ZLD)

\section{Introduction}

The world population is growing, and sustainable and responsible food production is important to ensure sufficient food supplies. One of the requirements for proper plant growth is a sufficient amount of phosphorus [1] which is mainly obtained by mining phosphorus rock. As much as $80 \%$ of total phosphorus is subsequently used to produce fertilizers for agriculture [2], thus making phosphorus an irreplaceable component of this sector. However, natural phosphorus reserves are depleting, and their quality is falling [3]. The available reserves of phosphorus rock are estimated to last only another 50-300 years [4,5]. Moreover, the availability of phosphorus rock may also be influenced by political, economic, and geographic situations in the site of the rock deposit $[4,6]$. Already in 2014, the mineral resource of phosphorus was identified as critical by the European Union [7].

However, phosphorus is regarded differently by farmers and wastewater treatment plant operators. Farmers perceive phosphorus as a necessary component for growing crops, while sewage treatment plant operators approach it as a waste substance to dispose of [4]. A solution is seen in the recovery of phosphorus after its primary use, e.g., from wastewater. In addition, increased concentrations of phosphorus in water recipients cause 
eutrophication, which has become a global issue [1]. Overall, the increasing demands for raw materials call for the implementation of circular economy models and the recovery of secondary raw materials from waste products.

In wastewater management it is advisable to proceed as far as zero liquid discharge (ZLD) $[6,8]$. ZLD is a series of processes aiming to eliminate the aqueous fraction of waste, recover secondary raw materials, and reuse the purified water. Such solutions are particularly suitable for urban environments with well-built networks of sewage treatment plants, leading to the recovery of the substances contained in the wastewater and the water itself [2]. This can also solve the issue of higher amounts of nutrients in water recipients, which causes eutrophication, and a renewable source of phosphorus for agriculture.

The current methods of removing and extracting phosphorus from wastewater include physical, chemical, biological, and physicochemical methods [9-11]. Considering all the available options and factors, a feasible solution lies in the precipitation of magnesium ammonium phosphate (struvite). The solution is based on the combination of physicochemical methods with addition of magnesium [12]. In wastewater treatment plants, struvite naturally forms in wastewater rich in phosphorus and nitrogen under co-occurrence of magnesium and appropriate $\mathrm{pH}$ value [13]. For wastewater treatment plant operators, the spontaneous precipitation of struvite in technological devices, such as pumps and pipes, is a big issue because these precipitates are very difficult and expensive to remove [14]. Targeted precipitation of struvite as a white, water-soluble, crystalline substance, suitable for fertilizing agricultural soil is carried out in the molar ratio $\mathrm{Mg}^{2+}: \mathrm{PO}_{4}^{3-}: \mathrm{NH}_{4}{ }^{+}$in 1:1:1 $[2,15]$. This precipitation reaction can be expressed by a simplified Equation (1).

$$
\mathrm{Mg}^{2+}+\mathrm{NH}_{4+}+\mathrm{PO}_{4}{ }^{3-}+6 \mathrm{H}_{2} \mathrm{O} \rightarrow \mathrm{MgNH}_{4} \mathrm{PO}_{4} \times 6 \mathrm{H}_{2} \mathrm{O}
$$

Scientists are looking for new ways of sourcing struvite and governments are optimizing laws to legalize struvite as a fertilizer. For example, the European Union Regulation (EU) 2019/1009 in [16] of the European Parliament and of the Council says that the market demand for struvite as a fertilizer has been identified, and also anticipates the related scientific analyses to be launched to deal with the present requirements in connection with the use of struvite in the EU internal market [16]. For example, Cai et al. in [10] conducted a pilot study of the extraction of phosphorus from synthetic wastewater using electrodialysis (ED) with magnesium anode, where, at optimum $\mathrm{pH} 8.8$ and $200 \mathrm{~L} / \mathrm{s}$ flow, the phosphate concentration in the diluate was detected as $0.5 \mathrm{mg} / \mathrm{L}$, compared to the $10 \mathrm{mg} / \mathrm{L}$ in the input flow. The authors set the price of $1 \mathrm{~kg}$ of phosphate obtained by this method at USD 31.27 [10]. Thant Zin and Kim in [17] investigated the extraction of struvite from nutrient-rich wastewater from the food industry and sewage sludge using Mg-Biochar. This biochar, on which magnesium is impregnated, is used as an ingredient necessary for struvite precipitation. Mg-Biochar prepared this way subsequently undergoes physical and chemical adsorption of $\mathrm{NH}_{4}-\mathrm{N}$ and $\mathrm{PO}_{4}-\mathrm{P}$. The authors state that struvite was the most represented precipitate on the surface of $\mathrm{Mg}$-Biochar and describe this method as promising for commercial use [17].

However, it is also necessary to observe the amount of heavy metals that can transfer into the struvite precipitate. For example, Huang et al. in [18] observed the effect of process parameters on the amount of heavy metals in struvite, namely $\mathrm{Zn}^{2+}, \mathrm{Cu}^{2+}$, and $\mathrm{Cr}^{3+}$. The measurements were performed on struvite extracted from synthetic wastewater from pig farming. They found that the increasing $\mathrm{pH}$ from 8 to 10.5 leads to a decrease in the content of these heavy metals. The contents of heavy metals were also affected by the molar ratio of total ammonia nitrogen (TAN) to phosphate phosphorus $\left(\mathrm{PO}_{4}-\mathrm{P}\right)$. Increasing the TAN: $\mathrm{PO}_{4}{ }^{-}$ $P$ ratio from 1:1 to 11:1 has a positive effect on reducing the concentrations of heavy metals. On the other hand, $\mathrm{Mg}: \mathrm{PO}_{4}-\mathrm{P}$ molar ratio was found as unimportant. In conclusion, the authors state that a consistent setting of parameters, namely TAN concentration and $\mathrm{pH}$, is the way to significantly reduce the heavy metal content during struvite precipitation [18].

Sýkorová et al. in [19] claim that some wastewaters are not suitable for struvite recovery due to low nutrient contents. Not only wastewater treatment operators need to 
deal with struvite formation, but researchers have also been looking for ways to reuse treated wastewaters, especially in connection with prolonged periods of drought [20].

Based on the above, the main goal of this study was to concentrate the phosphates in real dewatering liquor from wastewater treatment plant (WWPT) by electrodialysis (ED) and to obtain struvite by precipitation from the concentrate. In addition, the so-called diluate is formed, which can be used, for example, as water for irrigation. Therefore, we can simultaneously obtain struvite and irrigation water from WWPT dewatering liquor.

The aim was also to approach the goals of zero liquid discharge (ZLD). For the full implementation of ZLD it is important to solve the last step, which is dealing with the aqueous waste from struvite precipitation. However, this is still a matter of active research.

\section{Materials and Methods}

\subsection{Dewatering Liquor (DL)—Graphical Representation of the Procedure}

Raw DL is a waste product from anaerobic digestion and currently is pumped back into the WWTP inflow because it is still highly polluted and cannot be used or discharged untreated. It has no direct use either. In line with the valid legislation in the Czech Republic (according to ČSN 757143 in [21]) it cannot be even used as irrigation water as the value of dissolved solids exceeds the limit set in the Standard three times and places it in the category of water "unsuitable for irrigation".

Figure 1 below describes the current practice (in black color). Note that standard WWTPs are not equipped with struvite precipitation technology. To better understand our experiments, we added our solution into the current block diagram (in red color), where dewatering occurs is two stages.

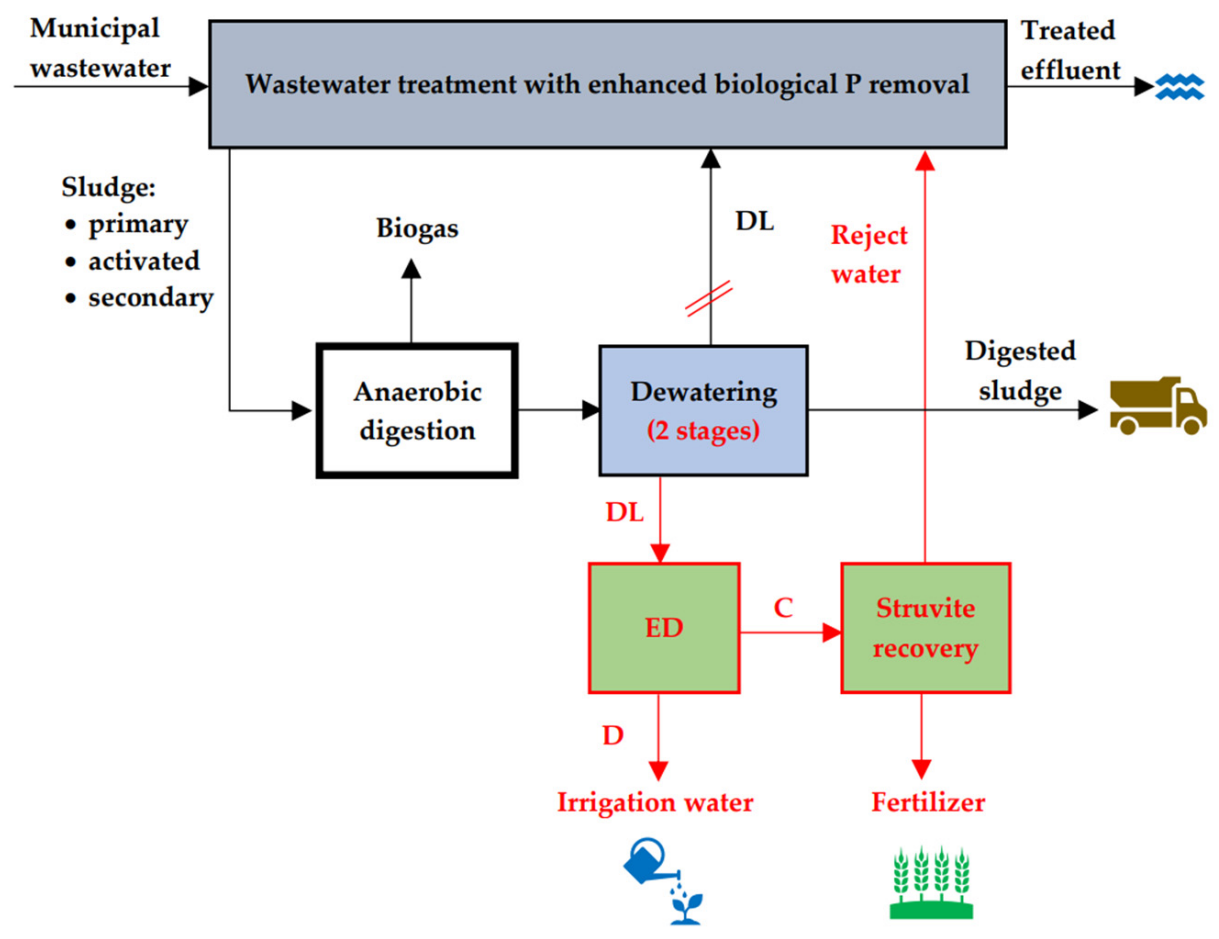

Figure 1. Contrasting the existing WWTP practice and our proposed solution incorporating ED into municipal WWTPs (where: black color describes the existing practice, and red color represents our solution). Note that DL is dewatering liquor, $\mathrm{C}$ is concentrate, and $\mathrm{D}$ is diluate.

DL is further concentrated using electrodialysis (ED). Struvite is precipitated from the concentrate (C), and the reject water is discharged into the inflow into the WWTP. At the same time, the diluate (D) can also be used, for example, as water for irrigation. 


\subsection{Samples}

Three $20 \mathrm{~L}$ samples of dewatering liquor were collected from outlet of sludge decanter of a municipal WWTP with the 88,000-population equivalent (Karviná, Czech Republic) every four weeks during spring of 2020 (from March to May). Normally, this DL is fed as an inflow to the WWTP. The DL was filtered by $\alpha$-cellulose membrane filter Munktell Ahlstrom 390, Ahlstrom-Munksjö, Helsinki, Finland (particle capture 3-5 $\mu \mathrm{m}$ ) and the physicochemical parameters of the treated DL (after filtration) samples are given in Table 1. DL samples treated in this way were the input DL for electrodialysis (ED) to recover struvite from concentrate, and irrigation water from diluate.

Table 1. Physicochemical parameters of input DL.

\begin{tabular}{ccccc}
\hline Parameter & Unit & $\begin{array}{c}\text { Sample 1 } \\
\text { (March 2020) }\end{array}$ & $\begin{array}{c}\text { Sample 2 } \\
\text { (April 2020) }\end{array}$ & $\begin{array}{c}\text { Sample 3 } \\
\text { (May 2020) }\end{array}$ \\
\hline $\mathrm{pH}$ & $(-)$ & 8.12 & 8.23 & 8.01 \\
\hline Conductivity & $(\mathrm{mS} / \mathrm{cm})$ & 8.02 & 7.94 & 8.10 \\
\hline Temperature & $\left({ }^{\circ} \mathrm{C}\right)$ & 20.60 & 20 & 20.10 \\
\hline Turbidity & $(\mathrm{NTU})$ & 255 & 260 & 250 \\
\hline $\mathrm{N}_{\text {total }}$ & $(\mathrm{mg} / \mathrm{L})$ & 1540 & 1380 & 1700 \\
\hline $\mathrm{NH}_{4}{ }^{+}$ & $(\mathrm{mg} / \mathrm{L})$ & 1112 & 1118 & 1106 \\
\hline $\mathrm{PO}_{4}{ }^{3-}$ & $(\mathrm{mg} / \mathrm{L})$ & 420 & 423 & 417 \\
\hline $\mathrm{Mg}^{2+}$ & $(\mathrm{mg} / \mathrm{L})$ & 21 & 19 & 25 \\
\hline $\mathrm{COD}_{\mathrm{Cr}}$ & $(\mathrm{mg} / \mathrm{L})$ & 319 & 323 & 2803 \\
\hline $\mathrm{DS}_{105}$ & $(\mathrm{mg} / \mathrm{L})$ & 2595 & 2417 & \\
\hline
\end{tabular}

Note: Power of hydrogen, conductivity, and temperature were measured by WTW GmBH Multi340i, WTW, Prague, Czech Republic; turbidity was measured according Standard ČSN EN ISO 7027-1 [22]; $\mathrm{N}_{\text {total }}$ was measured according Standard ČSN EN ISO 11905-1 [23]; $\mathrm{PO}_{4}{ }^{3-}$ was measured according Standard ČSN EN ISO 6878 [24]; $\mathrm{Mg}^{2+}$ was measured spectrometrically according to Standard ČSN EN ISO 15587-2 [25]; COD was measured according to Standard ČSN ISO 6060 [26]; DS 105 was measured gravimetrically according to Standard ČSN 757346 [27]. Note: measurement uncertainty-pH up to 3\%, other indicators up to $5 \%$.

\subsection{Electrodialysis (ED)}

Electrodialysis (ED) is an electrochemical membrane process. Electrodialysis transfers ions by using direct current as a driving force. Cation- and anion-exchange membranes are arranged alternately between electrode cells at both ends, and desalination and concentration are carried out utilizing the selectivity that these membranes can provide [28].

ED laboratory unit type EDR-Z (MEGA, Stráž pod Ralskem, Czech Republic) of P series with automatic voltage regulation was used to concentrate phosphorus in batch process. The ED module of EDR-Z/10-0.8 consists of two titan electrodes with a platinum layer and polarity reversal. The important ED module specifications and operating working parameters are summarized in Table 2. As mentioned above, two products were obtained during ED from the input DL: diluate and concentrate. For the struvite recovery experiments we needed $8 \mathrm{~L}$ of concentrate from each sample. Desalination (concentration) was performed in batch mode in a ratio of diluate to concentrate 1:1. The voltage on the module was $14 \mathrm{~V}$. A $2 \% \mathrm{Na}_{2} \mathrm{SO}_{4}$ solution was used as the electrode solution. From each sample of input DL there were 4 batch desalination tests adding up to $8 \mathrm{~L}$ of composite diluate and $8 \mathrm{~L}$ of composite concentrate obtained from each sample of input DL (the $\mathrm{pH}$ and concentrations of the observed metals are summarized in Section 3.3). A salt test with $2 \% \mathrm{Na}_{2} \mathrm{SO}_{4}$ was performed before and after DL ED to control ED module assembly and membrane fouling. Then, the ED module was cleaned and regenerated according to the recommendations of the ED manufacturer. 
Table 2. ED module specifications and operating working parameters.

\begin{tabular}{cc}
\hline Parameter & Value \\
\hline Effective area of ED module & $1344 \mathrm{~cm}^{2}$ \\
\hline Effective area of one membrane & $64 \mathrm{~cm}^{2}$ \\
\hline Number of membrane pairs in ED module & $10 \mathrm{pcs}$ \\
\hline Anion-exchange membrane RALEX ${ }^{\circledR} \mathrm{AM}(\mathrm{H})$-PES & $10 \mathrm{pcs}$ \\
\hline Cation-exchange membrane RALEX ${ }^{\circledR} \mathrm{CM}(\mathrm{H})$-PES & $11 \mathrm{pcs}$ \\
\hline PP spacer (thickness) & $20 \mathrm{pcs}(0.8 \mathrm{~mm})$ \\
\hline Electrodes (anode, cathode) Ti+Pt & $2 \mathrm{pcs}$ \\
\hline Hydraulic connection inner/outer & $\varnothing 6 / 8 \mathrm{~mm}$ \\
\hline ED module dimension $(1 \times \mathrm{w} \times \mathrm{h})$ & $1.5 \mathrm{~kg}$ \\
\hline ED module weight & $1-1.2 \mathrm{~V}$ \\
\hline Operating voltage (on membrane pair) & $30 \mathrm{~V}$ \\
\hline Max. voltage & $3 \mathrm{~mm} \times 250 \mathrm{~mm}$ \\
\hline Max. electrical current & $45-65 \mathrm{~L} / \mathrm{h}$ \\
\hline Operating flow rate of diluate, concentrate & $50-60 \mathrm{~L} / \mathrm{h}$ \\
\hline Operating flow rate of electrode solution & $20-30{ }^{\circ} \mathrm{C}$ \\
\hline Operating temperature &
\end{tabular}

Note: Capacity (batch process): $95 \%$ desalination of $1 \mathrm{~L}$ of $20 \mathrm{~g} / \mathrm{L} \mathrm{Na}_{2} \mathrm{SO}_{4}$ takes about $45 \mathrm{~min}$ at the temperature of $25^{\circ} \mathrm{C}$.

\subsection{Struvite Recovery}

Precipitation tests were realized in a jar stirrer (Lovibod ET 750, GmBH, Dortmund, Germany) in laboratory conditions. Phosphorus was precipitated from the ED concentrate into the form of struvite- $\mathrm{MgNH}_{4} \mathrm{PO}_{4} \times 6 \mathrm{H}_{2} \mathrm{O}$, having added magnesium in the form of granulated $\mathrm{MgSO}_{4} \times 7 \mathrm{H}_{2} \mathrm{O}$. The addition of two quantities of magnesium sulphate was tested; the first molar ratio was $\mathrm{PO}_{4}{ }^{3-}: \mathrm{Mg}^{2+} 1: 1$, and the second molar ratio was $\mathrm{PO}_{4}{ }^{3-}: \mathrm{Mg}^{2+} 1: 1.3$. Next, the $\mathrm{pH}$ value of the solution was modified to 9 by $10 \% \mathrm{NaOH}$. The solutions were stirred at mixing column $50 \mathrm{rpm}$ for $60 \mathrm{~min}$ and filtered. The obtained precipitate was left to dry in open air in laboratory conditions for $24 \mathrm{~h}$ before it was subjected to powder X-ray diffraction (XRD) analyses to identify the crystal phases of the precipitate (measurement uncertainty to $5 \%$ ). XRD analyses were carried out using a BrukerAXS D8 Advance instrument (Bruker, Mannheim, Germany) with a $2 \theta / \theta$ measurement geometry and the positionally sensitive detector LynxEye under the following conditions: radiation $\mathrm{CuK} \alpha / \mathrm{Ni}$ filter, current $40 \mathrm{kV}, 40 \mathrm{~mA}$ voltage, step mode with a step of $0.014^{\circ}$ $2 \theta$, and a total time of $15 \mathrm{~s}$ per step. Analysis of diffraction patterns was performed using the EVA software (Bruker-AXS, Mannheim, Germany) and the database PDF-2, release 2011 (International Centre for Diffraction Data, https:/ / www.icdd.com/pdf-2/ (accessed 18 November 2021). The Rietveld method using the TOPAS software, version 4.2 (Bruker, Mannheim, Germany) was applied to verify the qualitative analyses and for its quantification. The final percentages of the precipitated struvite obtained under two different doses of magnesium sulphate are given in Section 3.2.

\subsection{Heavy Metal and Dissolved Solids (DS) Analysis}

We assumed that the diluate stream may be applied for irrigation purposes in agriculture. However, because supernatant liquor may contain heavy metals, the diluate was analyzed using two methods. The first was atomic absorption spectrometry (AAS) using a device Varian AA280FS (Agilent, Santa Clara, CA, USA). The second method to trace heavy metals was inductively coupled plasma mass spectrometry (ICP-MS), and a device 
Analytik Jena GmbH PlasmaQuant MS Elite (Jena, Germany). The samples decomposition proceeded according to the Standard ČSN EN ISO 15587-2 [25].

\section{Results and Discussion}

\subsection{Electrodialysis (ED)}

The desalination of $2 \mathrm{~L}$ of the DL feed took $90 \mathrm{~min}$ on average. The resulting conductivity of the composite diluates and composite concentrates are shown in Table 3. The effect of membrane fouling was manifested by the prolongation of the time between individual batch tests by approximately $3 \mathrm{~min}$, i.e., the 4 th batch test lasted $99 \mathrm{~min}$.

Table 3. Conductivity of input DL and ED products.

\begin{tabular}{cccccc}
\hline Sample 1 & $\begin{array}{c}\text { Conductivity } \\
(\mathbf{m S / c m})\end{array}$ & Sample 2 & $\begin{array}{c}\text { Conductivity } \\
(\mathbf{m S / c m})\end{array}$ & Sample 3 & $\begin{array}{c}\text { Conductivity } \\
(\mathbf{m S / c m})\end{array}$ \\
\hline Input DL & 8.02 & Input DL & 7.94 & Input DL & 8.10 \\
\hline Concentrate & 15.23 & Concentrate & 15.08 & Concentrate & 15.60 \\
\hline Diluate & 0.33 & Diluate & 0.30 & Diluate & 0.38 \\
\hline
\end{tabular}

Note: Conductivity was measured by WTW GmBH Multi340i, WTW, Prague, Czech Republic. Measurement uncertainty up to $5 \%$.

\subsection{Struvite Recovery}

The final percentages of the precipitated struvite obtained under two different doses of magnesium sulphate of individual samples are given in Table 4 below. Figures 2 and 3 show the XRD patterns of Sample 1 precipitate (enlarged the hazenite curves peaks).

Table 4. Percentages of phase values obtained from precipitates identified using XRD method.

\begin{tabular}{|c|c|c|c|c|}
\hline \multirow{2}{*}{$\begin{array}{c}\text { Molar Ratio } \\
\text { Phase (\%) }\end{array}$} & \multicolumn{2}{|c|}{$\mathrm{PO}_{4}{ }^{3-}: \mathrm{Mg}^{2+} 1: 1$} & \multicolumn{2}{|c|}{$\mathrm{PO}_{4}{ }^{3-}: \mathrm{Mg}^{2+} 1: 1.3$} \\
\hline & Struvite & Hazenite & Struvite & Hazenite \\
\hline Sample 1 & 95 & 5 & 97 & 3 \\
\hline Sample 2 & 93 & 7 & 97 & 3 \\
\hline Sample 3 & 94 & 6 & 98 & 2 \\
\hline
\end{tabular}

Note: Measurement uncertainty up to $5 \%$.

Rietveld reliable factors are $R_{w p} 16.32, R_{p} 12.38$ in molar ratio 1:1, and $R_{w p} 14.89, R_{p}$ 11.26 in molar ratio 1:1.3. The peaks may be asymmetrical due to the occurrence of several struvite modifications, see studies by Meira et al. in [29] and Heraldy et al. in [30], where the peaks are also asymmetrical.

The results imply that the supernatant concentrate from ED may be used to precipitate phosphorus in the form of struvite. The obtained precipitate contained at least $93 \%$ of struvite, while the remaining percentage was represented by hazenite $\left(\mathrm{KNaMg}_{2}\left(\mathrm{PO}_{4}\right)_{2} \cdot \times\right.$ $\left.14 \mathrm{H}_{2} \mathrm{O}\right)$.

During the experiments we compared two molar ratios of $\mathrm{PO}_{4}^{3-}: \mathrm{Mg}^{2+}$ as the ratios represent an important part of phosphorus precipitation into the form of struvite [31]. In comparison with Sýkorová et al. in [19] when at best, they obtained a precipitate in the amount of $0.54 \mathrm{~g} / \mathrm{L}$ of "raw" dewatering liquor (without concentration), of which $40 \%$ were struvite crystals. In our proposed procedure, i.e., concentration of DL and precipitation of struvite in concentrate, the average yield of precipitate per $1 \mathrm{~L}$ of concentrate was $10 \mathrm{~g}$ of wet precipitate from $1 \mathrm{~L}$ of concentrate (molar ratio 1:1). The $10 \mathrm{~g}$ of wet precipitate included $19.25 \%$ of dry solids. Using the molar ratio 1:1.3 we obtained $12 \mathrm{~g}$ of wet precipitate (including $15.91 \%$ of dry solids). This way, $1 \mathrm{~L}$ of concentrate produced $1.83 \mathrm{~g}$ of crystalline phase with $94 \%$ struvite content, i.e., $1.72 \mathrm{~g}$ of crystal struvite (molar ratio 1:1) and $1.85 \mathrm{~g}$ of crystalline phase with $97 \%$ struvite content, i.e., $1.79 \mathrm{~g}$ of crystal struvite (molar ratio 1:1.3). 


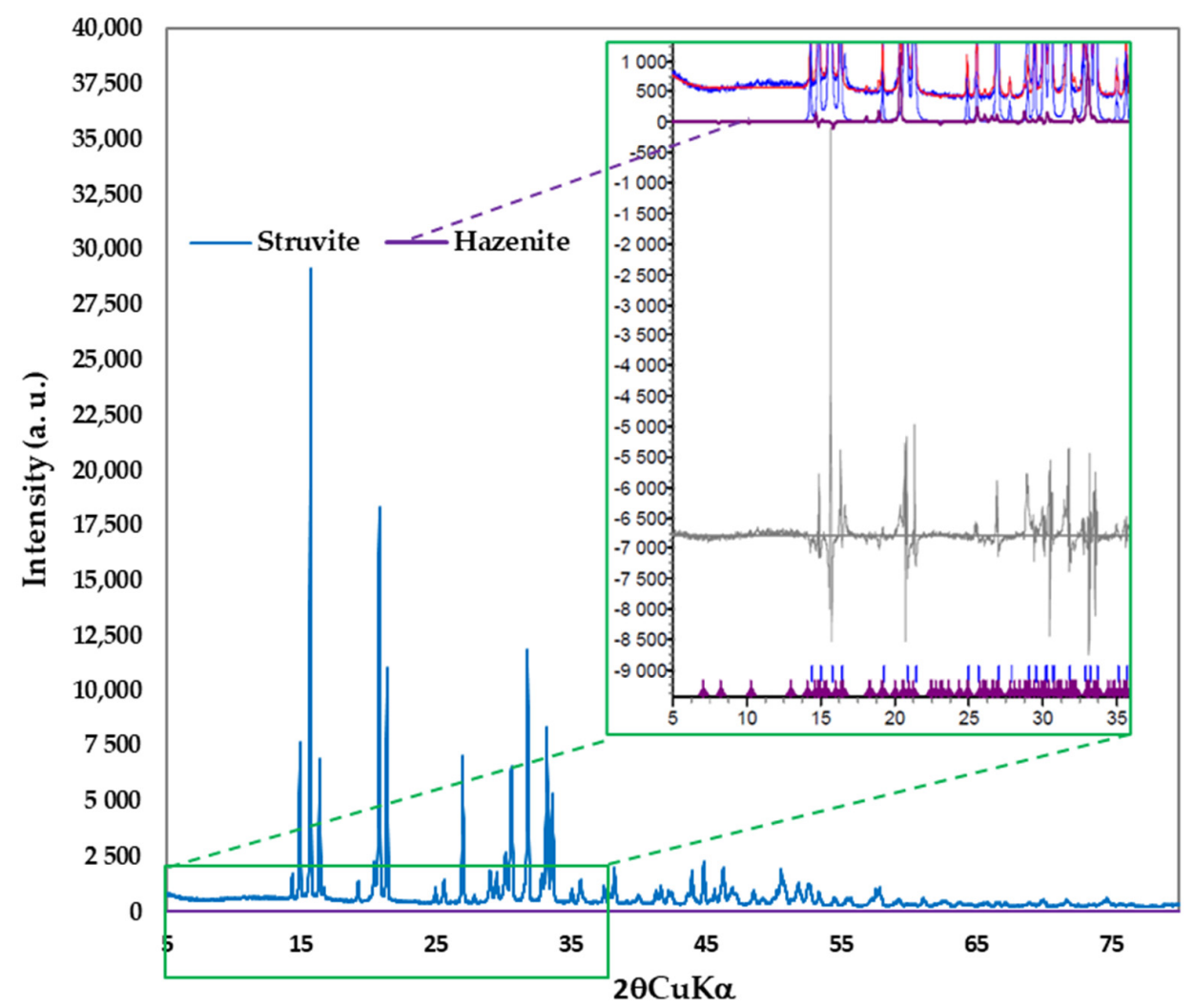

Figure 2. XRD pattern of precipitate Sample 1 -molar ratio $\mathrm{PO}_{4}{ }^{3-}: \mathrm{Mg}^{2+} 1: 1$.

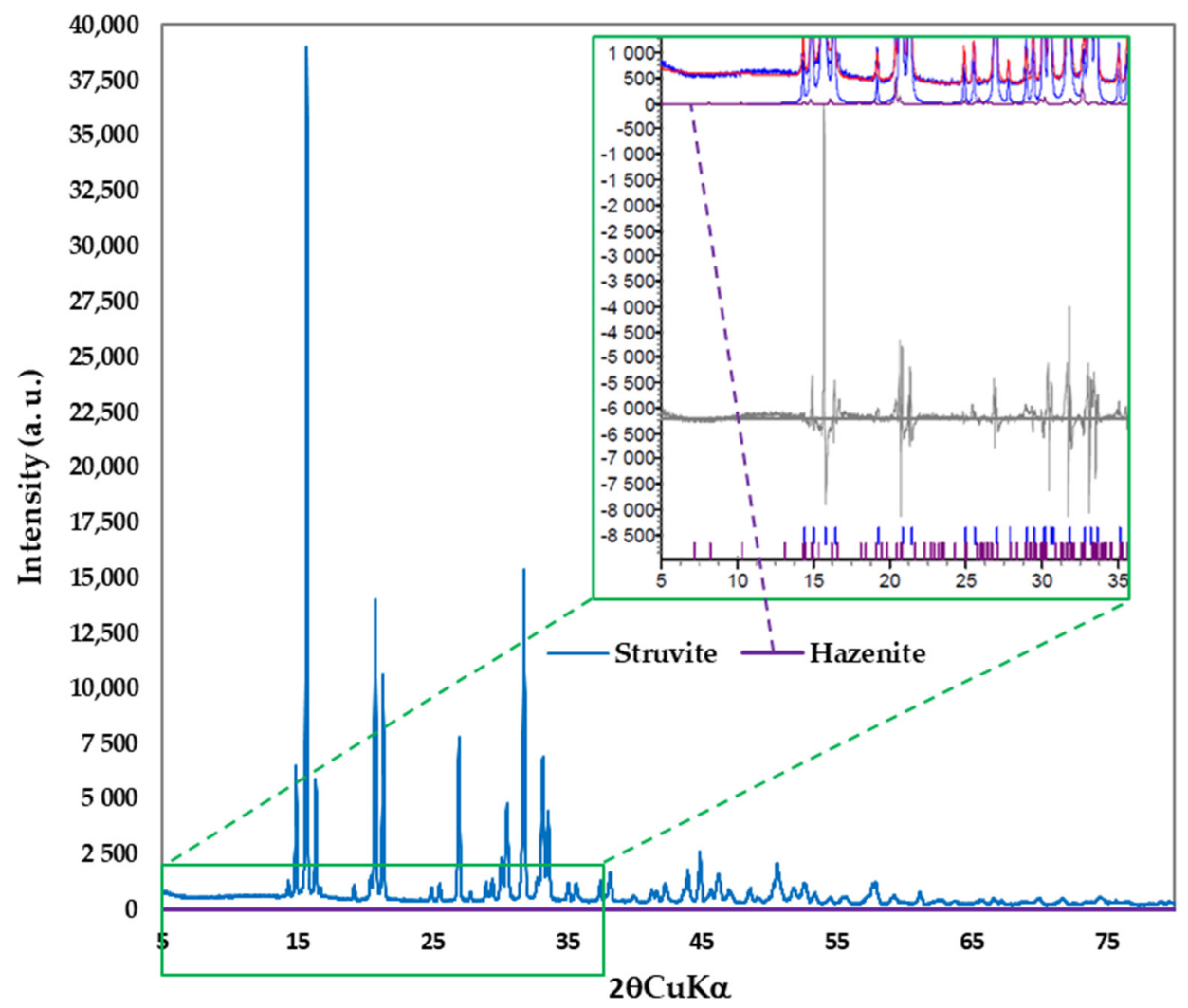

Figure 3. XRD pattern of precipitate Sample $1-$ molar ratio $\mathrm{PO}_{4}{ }^{3-}: \mathrm{Mg}^{2+} 1: 1.3$. 


\subsection{Heavy Metal, Phosphate, and Dissolved Solids (DS) Analysis}

Using AAS and ICP-MS we identified the concentrations of selected heavy metals in the input wastewater, the obtained diluate, and the concentrate. The values were compared with those stated in Standard ČSN 757143 [21], which is a document regulating conditions for water irrigation purposes. The concentrations of the measured heavy metals are stated in Table 5. The effect of ED on the concentration of heavy metals was not significant. This phenomenon is related to the permeability of the membranes and the degree of dissociation of individual metals and their ionic size, when in the ED process they pass between the diluate and the concentrate.

Table 5. Values of heavy metals in ED products of samples 1-3.

\begin{tabular}{|c|c|c|c|c|c|c|c|c|c|c|}
\hline Sample 1 & $\begin{array}{c}\mathrm{pH} \\
(-)\end{array}$ & $\begin{array}{c}\mathrm{t} \\
\left({ }^{\circ} \mathrm{C}\right)\end{array}$ & $\begin{array}{c}\mathrm{Cd} \\
(\mathrm{mg} / \mathrm{L})\end{array}$ & $\begin{array}{c}\text { Co } \\
(\mathrm{mg} / \mathrm{L})\end{array}$ & $\mathrm{Cr}_{\text {total }}(\mathrm{mg} / \mathrm{L})$ & $\begin{array}{c}\mathrm{Cu} \\
(\mathrm{mg} / \mathrm{L})\end{array}$ & $\begin{array}{c}\mathrm{Ni} \\
(\mathrm{mg} / \mathrm{L})\end{array}$ & $\begin{array}{c}\mathrm{Pb} \\
(\mathrm{mg} / \mathrm{L})\end{array}$ & $\begin{array}{c}\mathrm{Zn} \\
(\mathrm{mg} / \mathrm{L})\end{array}$ & $\begin{array}{c}\mathrm{Fe} \\
(\mathrm{mg} / \mathrm{L})\end{array}$ \\
\hline Input DL & 8.12 & 20.60 & $<0.01$ & $<0.01$ & $<0.01$ & 0.042 & 0.029 & 0.003 & 0.109 & 1.570 \\
\hline Concentrate & 7.98 & 20.00 & $<0.01$ & $<0.01$ & $<0.01$ & 0.032 & 0.029 & 0.008 & 0.198 & 2.160 \\
\hline Diluate & 5.46 & 20.00 & $<0.01$ & $<0.01$ & $<0.01$ & 0.027 & 0.022 & 0.002 & 0.109 & 1.460 \\
\hline Sample 2 & $\begin{array}{c}\mathrm{pH} \\
(-)\end{array}$ & $\begin{array}{c}t \\
\left({ }^{\circ} \mathrm{C}\right)\end{array}$ & $\begin{array}{c}\mathrm{Cd} \\
(\mathrm{mg} / \mathrm{L})\end{array}$ & $\begin{array}{c}\text { Co } \\
(\mathrm{mg} / \mathrm{L})\end{array}$ & $\mathrm{Cr}_{\text {total }}(\mathrm{mg} / \mathrm{L})$ & $\begin{array}{c}\mathrm{Cu} \\
(\mathrm{mg} / \mathrm{L})\end{array}$ & $\begin{array}{c}\mathrm{Ni} \\
(\mathrm{mg} / \mathrm{L})\end{array}$ & $\begin{array}{c}\mathrm{Pb} \\
(\mathrm{mg} / \mathrm{L})\end{array}$ & $\begin{array}{c}\mathrm{Zn} \\
(\mathrm{mg} / \mathrm{L})\end{array}$ & $\begin{array}{c}\mathrm{Fe} \\
(\mathrm{mg} / \mathrm{L})\end{array}$ \\
\hline Input DL & 8.23 & 20.00 & $<0.01$ & $<0.01$ & $<0.01$ & 0.039 & 0.034 & 0.003 & 0.112 & 1.548 \\
\hline Concentrate & 8.01 & 20.00 & $<0.01$ & $<0.01$ & $<0.01$ & 0.033 & 0.031 & 0.008 & 0.195 & 2.165 \\
\hline Diluate & 5.84 & 20.00 & $<0.01$ & $<0.01$ & $<0.01$ & 0.025 & 0.025 & 0.002 & 0.111 & 1.488 \\
\hline Sample 3 & $\begin{array}{c}\mathrm{pH} \\
(-)\end{array}$ & $\begin{array}{c}\mathrm{t} \\
\left({ }^{\circ} \mathrm{C}\right)\end{array}$ & $\begin{array}{c}\mathrm{Cd} \\
(\mathrm{mg} / \mathrm{L})\end{array}$ & $\begin{array}{c}\text { Co } \\
(\mathrm{mg} / \mathrm{L})\end{array}$ & $\begin{array}{l}\mathrm{Cr}_{\text {total }} \\
(\mathrm{mg} / \mathrm{L})\end{array}$ & $\begin{array}{c}\mathrm{Cu} \\
(\mathrm{mg} / \mathrm{L})\end{array}$ & $\begin{array}{c}\mathrm{Ni} \\
(\mathrm{mg} / \mathrm{L})\end{array}$ & $\begin{array}{c}\mathrm{Pb} \\
(\mathrm{mg} / \mathrm{L})\end{array}$ & $\begin{array}{c}\mathrm{Zn} \\
(\mathrm{mg} / \mathrm{L})\end{array}$ & $\begin{array}{c}\mathrm{Fe} \\
(\mathrm{mg} / \mathrm{L})\end{array}$ \\
\hline Input DL & 8.01 & 20.10 & $<0.01$ & $<0.01$ & $<0.01$ & 0.045 & 0.024 & 0.003 & 0.106 & 1.556 \\
\hline Concentrate & 7.95 & 20.10 & $<0.01$ & $<0.01$ & $<0.01$ & 0.031 & 0.027 & 0.008 & 0.201 & 2.155 \\
\hline Diluate & 5.08 & 20.10 & $<0.01$ & $<0.01$ & $<0.01$ & 0.029 & 0.019 & 0.002 & 0.107 & 1.432 \\
\hline
\end{tabular}

Note: Measurement uncertainty- $\mathrm{pH}$ and t up to $3 \%$, metals up to $20 \%$.

Phosphate content in input and output streams is captured in Table 6. It is clear from the table that the phosphate concentration was doubled by ED. The results of the analysis of the filtrate show that phosphates precipitated with $99 \%$ efficiency.

Table 6. Phosphate content in input and output streams.

\begin{tabular}{cccccc}
\hline & Input DL & Concentrate & Diluate & $\begin{array}{c}\text { Filtrate After } \\
\text { Precipitation } \\
\text { Molar Ratio 1:1 }\end{array}$ & $\begin{array}{c}\text { Filtrate After } \\
\text { Precipitation } \\
\text { Molar Ratio 1:1.3 }\end{array}$ \\
\cline { 2 - 6 } & $\mathbf{( m g / L )}$ & $\mathbf{( m g / L )}$ & $\mathbf{( m g / L )}$ & $\mathbf{( m g / L )}$ & $\mathbf{( m g / L )}$ \\
\hline Sample 1 & 420 & 720 & 30 & 3.12 & 6.08 \\
\hline Sample 2 & 423 & 725 & 31 & 3.54 & 6.71 \\
\hline Sample 3 & 417 & 710 & 25 & 2.75 & 6.25 \\
\hline
\end{tabular}

Note: Measurement uncertainty up to $5 \%$.

Due to its composition, dewatering liquor (DL) falls into the category of water "unsuitable for irrigation" (see Table 1). This can be evaluated, for example, on the indicator "DS", when the value measured in DL is in the range of $2500-2800 \mathrm{mg} / \mathrm{L}$, while according to Czech Standard ČSN 757143 [21] is the limit for suitable resp. conditionally suitable less than 800 resp. $1200 \mathrm{mg} / \mathrm{L}$. For this reason, DL is not suitable for irrigation.

The diluate parameters (see Table 7) may be classified as Category I water-i.e., water suitable for irrigation. The greatest decrease was manifested in DS or in the conductivity of 
the diluate when the DS decreased on average by $93 \%$ compared to the input values. The monitored heavy metals also meet the requirements for irrigation-Category I.

Table 7. Classification of the different sample parameters into water quality classes according to Standard ČSN 757143.

\begin{tabular}{|c|c|c|c|c|c|c|c|}
\hline \multirow{2}{*}{ Parameter } & \multirow{2}{*}{ Unit } & \multirow{2}{*}{ Diluate 1} & \multirow{2}{*}{ Diluate 2} & \multirow{2}{*}{ Diluate 3} & \multicolumn{3}{|c|}{ Standard ČSN 757143} \\
\hline & & & & & Category I* & Category II ** & Category III *** \\
\hline $\mathrm{pH}$ & $(-)$ & 5.46 & 5.84 & 5.08 & 5 to 8.5 & 4.5 to 9 & $<4.5$ to $>9$ \\
\hline $\mathrm{t}$ & $\left({ }^{\circ} \mathrm{C}\right)$ & 20.00 & 20.00 & 20.10 & 35 & 40 & $>40$ \\
\hline $\mathrm{DS}_{105}$ & $(\mathrm{mg} / \mathrm{L})$ & 176.00 & 182.25 & 150.84 & 800 & 1,200 & $>1,200$ \\
\hline $\mathrm{Cd}$ & $(\mathrm{mg} / \mathrm{L})$ & $<0.01$ & $<0.01$ & $<0.01$ & 0.01 & 0.02 & $>0.02$ \\
\hline Co & $(\mathrm{mg} / \mathrm{L})$ & $<0.01$ & $<0.01$ & $<0.01$ & 0.5 & 1 & $>1$ \\
\hline $\mathrm{Cr}_{\text {total }}$ & $(\mathrm{mg} / \mathrm{L})$ & $<0.01$ & $<0.01$ & $<0.01$ & 0.2 & 0.5 & $>0.5$ \\
\hline $\mathrm{Cu}$ & $(\mathrm{mg} / \mathrm{L})$ & 0.027 & 0.025 & 0.029 & 0.5 & 2 & $>2$ \\
\hline $\mathrm{Ni}$ & $(\mathrm{mg} / \mathrm{L})$ & 0.022 & 0.025 & 0.019 & 0.1 & 0.2 & $>0.2$ \\
\hline $\mathrm{Pb}$ & $(\mathrm{mg} / \mathrm{L})$ & 0.002 & 0.002 & 0.002 & 0.05 & 0.1 & $>0.1$ \\
\hline $\mathrm{Zn}$ & $(\mathrm{mg} / \mathrm{L})$ & 0.109 & 0.111 & 0.107 & 1 & 2 & $>2$ \\
\hline $\mathrm{Fe}$ & $(\mathrm{mg} / \mathrm{L})$ & 1.460 & 1.488 & 1.432 & 10 & 100 & $>100$ \\
\hline
\end{tabular}

Note: Measurement uncertainty- $\mathrm{pH}$ and $\mathrm{t}$ up to $3 \%$, metals up to $20 \%$. Note: Category I ${ }^{*}$ water suitable for irrigation; Category II ** water conditionally suitable for irrigation; Category III *** water unsuitable for irrigation.

However, more detailed research is needed before such water can be used for irrigation purposes, especially various biological indicators must be tested.

Nowadays, there are numerous countries facing the problem of clean water supply shortage. In $[32,33]$ the authors summarize the pros and cons of using treated wastewater for irrigation purposes. They conclude that there are more advantages to the approach. The drawbacks lie in the likelihood of high heavy metals concentrations in irrigation water, which shall transfer into the soil and crops, and related health risks. However, the advantages are seen in dealing with water shortages, especially in dry regions, or areas with minimum sources of drinking water. Another benefit is nutrients for crops and soil through irrigation, and thus high crop yields [33].

The main contribution of our research lies in the usage of the ED products of diluate and concentrate from DL. The concentrate contains the ions required for the chemical precipitation of phosphorus under the formation of struvite precipitate. This way, phosphorus gets recycled in the form of fertilizer, which has been known for its low solubility and good fertilizing properties. The second product is the diluate stream, which we classified into Category I-water suitable for irrigation according to Standard ČSN 757143 in [21], thus rendering the diluate stream a potential irrigation water resource, especially for areas with limited access to water. All the residual liquid wastes may be recycled, i.e., incorporated into sludge management or re-fed as the inflow of municipal WWTP.

\section{Conclusions}

In view of the fact that phosphorus is one of the critical raw materials of the 21st century, it can be expected that the recovery of phosphorus will become part of wastewater treatment sludge management. In addition, we face more frequent occurrences of drought, so we need to look for alternative sources of water. On the other hand, the incorporation of a struvite recovery technology will undoubtedly be a costly investment.

The aim of this research was to reuse ED products obtained from DL treatment. The measured data show that both products can be reused in agriculture. From a concentrated stream of ED concentrate, $\mathrm{MgNH}_{4} \mathrm{PO}_{4} \times 6 \mathrm{H}_{2} \mathrm{O}$-struvite, can be obtained by precipitation with the addition of $\mathrm{MgSO}_{4} \times 7 \mathrm{H}_{2} \mathrm{O}$ and $\mathrm{NaOH}$, which can be used as a fertilizer in agriculture. 
The yield of crystal struvite per $1 \mathrm{~L}$ of concentrate is $1.72 \mathrm{~g}$ (in molar ratio 1:1) and $1.79 \mathrm{~g}$ (in molar ratio 1:1.3). Based on our findings, the molar ratio 1:1 shows as effective and sufficient. In comparison with Sýkorová et al. in [19], where the authors obtained $0.21 \mathrm{~g}$ of crystal struvite in the best result, we obtained an eightfold amount of crystal struvite.

A more desalted ED stream-diluate can be used as irrigation water. The detected concentrations of heavy metals and DS in the diluate were compared with the standard ČSN 757143 in [21], which in the Czech Republic sets conditions for water suitable for irrigation. By comparing the determined values of heavy metal and DS concentrations with the values given in the relevant standard, it was found that the analyzed samples of diluate belong to Category I, i.e., water suitable for irrigation. To close the ZLD cycle, the remaining liquid waste can be recycled within sludge management of municipal WWTP. In further research, attention should be paid to the hygienic security of the resulting products and to the possibilities of alkali recovery by electrodialysis with bipolar membranes (EDBM).

Author Contributions: P.M., K.C. were responsible for the conceptualization, investigation, methodology, desalination, and wrote the original draft of the manuscript; S.H. was responsible for the sampling, data curation, and supervision; J.H. was responsible for the formal analysis, resources, and for the writing-review and editing; I.K. was responsible for the methodology and analyzing; B.V. was responsible for the project administration and for the funding acquisition. All authors have read and agreed to the published version of the manuscript.

Funding: This research was funded by the Student Grant Competition financed by VSB-Technical University of Ostrava (no. SV54600B).

Institutional Review Board Statement: Not applicable.

Informed Consent Statement: Not applicable.

Data Availability Statement: Data sets are contained within the article. Further data and materials requests should be addressed to petra.malikova@vsb.cz (P.M.).

Acknowledgments: This paper was compiled within Student Grant Competition SGS 2020/121, Project SV54600B entitled 'Use of Sewage Sludge, Supernatant, and Non-Recyclable Waste Materials', financed by VSB-Technical University of Ostrava.

Conflicts of Interest: The authors declare no conflict of interest.

\section{References}

1. Rosemarin, A.; Macura, B.; Carolus, J.; Barquet, K.; Ek, F.; Järnberg, L.; Lorick, D.; Johannesdottir, S.; Pedersen, S.M.; Koskiaho, J.; et al. Circular nutrient solutions for agriculture and wastewater-A review of technologies and practices. Curr. Opin. Environ. Sustain. 2020, 45, 78-91. [CrossRef]

2. Rufí-Salís, M.; Brunnhofer, N.; Petit-Boix, A.; Gabarrell, X.; Guisasola, A.; Villalba, G. Can wastewater feed cities? Determining the feasibility and environmental burdens of struvite recovery and reuse for urban regions. Sci. Total Environ. 2020, 737, 139783. [CrossRef]

3. Li, B.; Li, P.; Zeng, X.C.; Yu, W.; Huang, Y.F.; Wang, G.Q.; Young, B.R. Assessing the sustainability of phosphorus use in China: Flow patterns from 1980 to 2015. Sci. Total Environ. 2020, 704, 135305. [CrossRef]

4. Cordell, D.; Drangert, J.-O.; White, S. The story of phosphorus: Global food security and food for thought. Glob. Environ. Change 2009, 19, 292-305. [CrossRef]

5. Yin, Z.; Chen, Q.; Zhao, C.; Fu, Y.; Li, J.; Feng, Y.; Li, L. A new approach to removing and recovering phosphorus from livestock wastewater using dolomite. Chemosphere 2020, 255, 127005. [CrossRef]

6. Tong, T.; Elimelech, M. The Global Rise of Zero Liquid Discharge for Wastewater Management: Drivers, Technologies, and Future Directions. Environ. Sci. Technol. 2016, 50, 6846-6855. [CrossRef] [PubMed]

7. EC MEMO 14/377. The European Critical Raw Materials Review. European Commission. 2014. Available online: https: / / ec.europa.eu/commission/presscorner/detail/en/MEMO_14_377 (accessed on 29 November 2020).

8. Mavhungu, A.; Masindi, V.; Foteinis, S.; Mbaya, R.; Tekere, M.; Kortidis, I.; Chatzisymeon, E. Advocating circular economy in wastewater treatment: Struvite formation and drinking water reclamation from real municipal effluents. J. Environ. Chem. Eng. 2020, 8, 103957. [CrossRef]

9. Munir, M.T.; Li, B.; Mardon, I.; Young, B.R.; Baroutian, S. Integrating wet oxidation and struvite precipitation for sewage sludge treatment and phosphorus recovery. J. Clean. Prod. 2019, 232, 1043-1052. [CrossRef]

10. Cai, Y.; Han, Z.; Lin, X.; Duan, Y.; Du, J.; Ye, Z.; Zhu, J. Study on removal of phosphorus as struvite from synthetic wastewater using a pilot-scale electrodialysis system with magnesium anode. Sci. Total Environ. 2020, 726, 138221. [CrossRef] 
11. De-Bashan, L.E.; Bashan, Y. Recent advances in removing phosphorus from wastewater and its future use as fertilizer (1997-2003). Water Res. 2004, 38, 4222-4246. [CrossRef] [PubMed]

12. Kaszycki, P.; Głodniok, M.; Petryszak, P. Towards a bio-based circular economy in organic waste management and wastewater treatment-the Polish perspective. New Biotechnol. 2021, 61, 80-89. [CrossRef]

13. Sena, M.; Seib, M.; Noguera, D.R.; Hicks, A. Environmental impacts of phosphorus recovery through struvite precipitation in wastewater treatment. J. Clean. Prod. 2021, 280, 124222. [CrossRef]

14. Ghosh, S.; Lobanov, S.; Lo, V.K. An overview of technologies to recover phosphorus as struvite from wastewater: Advantages and shortcomings. Environ. Sci. Pollut. Res. 2019, 26, 19063-19077. [CrossRef]

15. Wang, Y.; Wang, X.; Li, J.; Li, Y.; Liu, Y.; Wang, F.; Zhao, J. Adsorption and precipitation behaviors of zinc, copper and tetracycline with struvite products obtained by phosphorus recovery from swine wastewater. J. Environ. Chem. Eng. 2020, 8, 104488. [CrossRef]

16. European Parliament. Regulation 2019/1009/EC of the European Parliament and of the Council of 5 June 2019 Laying Down Rules on the Making Available on the Market of EU Fertilising Products and Amending Regulations (EC) No 1069/2009 and (EC) No 1107/2009 and Repealing Regulation (EC) No 2003/2003; European Parliament: Brussels, Belgium, 2019; Available online: http:/ / data.europa.eu / eli/reg/2019/1009/oj (accessed on 8 October 2021).

17. Thant Zin, M.M.; Kim, D.-J. Simultaneous recovery of phosphorus and nitrogen from sewage sludge ash and food wastewater as struvite by Mg-biochar. J. Hazard. Mater. 2021, 403, 123704. [CrossRef] [PubMed]

18. Huang, H.; Li, B.; Li, J.; Zhang, P.; Yu, W.; Zhao, N.; Guo, G.; Young, B. Influence of process parameters on the heavy metal $\left(\mathrm{Zn}_{2}{ }^{+}\right.$, $\mathrm{Cu}_{2}{ }^{+}$and $\mathrm{Cr}^{3+}$ ) content of struvite obtained from synthetic swine wastewater. Environ. Pollution. 2019, 245, 658-665. [CrossRef]

19. Sýkorová, E.; Wanner, J.; Beneš, O. Analysis of phosphorus recovery by struvite precipitation from sludge water in selected wastewater treatment plants. Chemické Listy 2014, 108, 610-614.

20. Muhmood, A.; Lu, J.; Dong, R.; Wu, S. Formation of struvite from agricultural wastewaters and its reuse on farmlands: Status and hindrances to closing the nutrient loop. J. Environ. Manag. 2019, 230, 1-13. [CrossRef] [PubMed]

21. ČSN 75 7143. Water Quality for Irrigation; Czech Standards Institute: Prague, Czech Republic, 1992.

22. ČSN EN ISO 7027-1. Water Quality—Determination of Turbidity_Part 1: Quantitative Methods; Czech Office for Standards, Metrology and Testing: Prague, Czech Republic, 2017.

23. ČSN EN ISO 11905-1. Water Quality—Determination of Nitrogen—Part 1: Method Using Oxidative Digestion with Peroxodisulfate; Czech Office for Standards, Metrology and Testing: Prague, Czech Republic, 2017.

24. ČSN EN ISO 6878. Water Quality—Determination of Phosphorus-Ammonium Molybdate Spectrometric Method; Czech Standards Institute: Prague, Czech Republic, 2005.

25. ČSN EN ISO 15587-2. Water Quality—Digestion for the Determination of Selected Elements in Water-Part2: Nitric Acid Digestion; Czech Standards Institute: Prague, Czech Republic, 2004.

26. ČSN ISO 6060. Water Quality_Determination of the Chemical Oxygen Demand; Czech Office for Standards, Metrology and Testing: Prague, Czech Republic, 2009.

27. ČSN 757346 Water Quality—Determination of Dissolved Solids; Czech Standards Institute: Prague, Czech Republic, 2002.

28. Richard, W.B. Membrane Technology and Research, 3rd ed.; John Wiley \& Sons Ltd.: Chichester, UK, 2012; p. 588. ISBN 978-1-11835969-3.

29. Meira, R.C.S.; Paz, S.A.P.; Corrêa, J.A.M. XRD-Rietveld analysis as a tool for monitoring struvite analog precipitation from wastewater: P, Mg, N and K recovery for fertilizer production. J. Mater. Res. Technol. 2020, 9, 15202-15213. [CrossRef]

30. Heraldy, E.; Rahmawati, F.; Putra, H.; Putra, D.P. Application of quantitative XRD on the precipitation of struvite from Brine Water. IOP Conf. Ser. Mater. Sci. Eng. 2017, 172, 012015. [CrossRef]

31. Stanclik, A.; Hutnik, N.; Matynia, A.; Gluzinska, J.; Piotrowski, K. Recovery of phosphate (V) ions from liquid waste solutions containing organic impurities. Chemic Sci.-Tech.-Market 2011, 65, 675-686.

32. Guadie, A.; Yesigat, A.; Gatew, S.; Worku, A.; Liu, W.; Ajibade, F.O.; Wang, A. Evaluating the health risks of heavy metals from vegetables grown on soil irrigated with untreated and treated wastewater in Arba Minch, Ethiopia. Sci. Total. Environ. 2020, 761, 143302. [CrossRef] [PubMed]

33. Ofori, S.; Puškáčová, A.; Růžičková, I.; Wanner, J. Treated wastewater reuse for irrigation: Pros and cons. Sci. Total. Environ. 2021, 760, 144026. [CrossRef] [PubMed] 